\title{
WYTYCZNE HETMANA WACLAWA RZEWUSKIEGO (1706-1779) DLA SŁUŻBY PAŁACOWEJ. PRZYCZYNEK DO FUNKCJONOWANIA REZYDENCJI PODHORECKIEJ W POLOWIE XVIII WIEKU
}

\begin{abstract}
Wstęp
Pałac w Podhorcach został zbudowany przez hetmana wielkiego koronnego i kasztelana krakowskiego Stanisława Koniecpolskiego (I594-I646) w latach I635-I640. Następnie właścicielami pałacu byli kolejno: przedstawiciele rodziny Koniecpolskich, Sobieskich, Rzewuskich oraz Sanguszków ${ }^{\mathrm{I}}$. Na początku XVIII wieku właścicielami rezydencji podhoreckiej była rodzina Rzewuskich. Władysław Kryczyński złotym czasem dla rezydencji określił okres, kiedy właścicielem pałacu był hetman wielki koronny Wacław Rzewuski (I706I779) ${ }^{2}$. Znajdująca się na południowych krańcach ówczesnej Rzeczypospolitej rezydencja od I729 roku była główną siedzibą hetmana. Wacław Rzewuski urządził w pałacu podhoreckim wspaniałą staropolską siedzibę magnacką, posiadającą pamiątki po przedstawicielach rodziny Sobieskich, Koniecpolskich, galerię dzieł sztuki, jak również zbrojownię z cennymi artefaktami oraz bibliotekę3. Stworzona przez Wacława Rzewuskiego siedziba magnacka w XVIII oraz XIX wieku, ze względu na swe duże znaczenie kulturalne, nazywana była
\end{abstract}

\footnotetext{
* Dr Katarzyna Paduch - historyk, absolwentka Uniwersytetu Kardynała Stefana Wyszyńskiego (2012), asystent w Instytucie Nauk Historycznych Wydziału Nauk Historycznych i Społecznych UKSW. Zainteresowania naukowe: historia kultury w XVIII w., dzieje rodu Rzewuskich h. Krzywda, gospodarka w dobrach magnackich. E-mail: k.paduch@uksw.edu.pl.

Zob. R. Aftanazy, Dzieje rezydencji na dawnych kresach Rzeczypospolitej, t. 7, Wrocław-Warszawa-Kraków 1995, s. 427-490; A. Czołowski, Dawne zamki i twierdze na Rusi Halickiej, „Teka Konserwatorska: rocznik Koła C.C. Konserwatorów Starożytnych Pomników Galicji Wschodniej”, 1892, t. 1, s. 96-100; K. Bańburski, A. Szpunar, Zamek w Podhorcach w posiadaniu Rzewuskich i Sanguszków, „Zamoysko-Wołyńskie Zeszyty Muzealne”, 2004, t. 2, s. 139-153; Z. Bania, Pałac w Podhorcach, „Rocznik Historii Sztuki”, 1981, t. 13, s. 97-170.

2 Zob. W. Kryczyński, Zamek w Podhorcach, Złoczów 1894, s. 25; Z. Zielińska, Rzewuski Wacław (1706-1779), w: Polski Słownik Biograficzny, t. 34, red. H. Markiewicz, Wrocław-Warszawa-Kraków 1992-1993, s. 169-180.

3 Zob. Z. Zielińska, op. cit., s. 169-180; T. Krzyżewski, Rzewuski Wacław (1706-1779), w: Słownik Pracowników Ksiązki Polskiej, red I. Treichel, Warszawa-Łódź 1972, s. 781-782; R. Aftanazy, op. cit., s. 441-447; K. Bańburski, A. Szpunar, op. cit., s. 141-145; J. M. Marszalska, Biblioteka i archiwum Sanguszków: zarys dziejów, Tarnów 2000, s. 127-141; J.K. Ostrowski, J.T. Petrus, Podhorce: dzieje wnętrz pałacowych i galerii obrazów, Kraków 2001, s. 31-38; K. Paduch, Biblioteka rodowa Rzewuskich h. Krzywda w Podhorcach w XVIII i XIX wieku, mps rozprawy doktorskiej, s. 39-44.
} 
„Wawelem Podola”, „Wawelem Wschodu”, „Pomnikiem Dawnego Rycerstwa Polskiego”, jak również „Panteonem Galicji”"4.

$\mathrm{Na}$ temat rezydencji podhoreckiej powstał szereg opracowań i artykułów5. Jednak dotychczas żaden z historyków badających pałac w Podhorcach nie podjął się próby przebadania rezydencji pod kątem funkcjonowania dworu w Podhorcach, chociażby w świetle zachowanych instrukcji oraz dokumentów archiwalnych pozostawionych przez hetmana Wacława Rzewuskiego. Maria Bogucka zauważa, iż badania nad szeroko pojętym ,życiem codziennym", czyli jak pisze badaczka m.in. warunkami egzystencji oraz pracy, dziejami rodziny, funkcjonowaniem i prowadzenie siedzib, poglądami, wierzeniami, mentalnością, stały się popularne w drugiej połowie XX wieku' ${ }^{6}$. Opracowanie funkcjonowania dworu magnackiego jest jednak niezwykle trudne. Jak zauważa Iwona Kulesza-Woronicka, materiał archiwalny dotyczący powyższego zagadnienia często jest rozproszony i wymaga dużych nakładów pracy ${ }^{7}$. To stwierdzenie może wyjaśnić, dlaczego do tej pory żaden badacz nie zajął się szczegółowym opracowaniem funkcjonowania dworu podhoreckiego Rzewuskich. Niniejszy artykuł stanowi próbę przedstawienia funkcjonowania rezydencji podhoreckiej w świetle instrukcji zachowanych w Księdze inwentarzowej i dyspozycji zamku w Podhorcach z lat $\mathrm{I} 745-\mathrm{I} 754^{8}$.

Wspomniana księga zawierająca dyspozycje wydane przez hetmana Wacława Rzewuskiego dla służby znajduje się w zasobach Archiwum Sanguszków, które obecnie przechowywane jest w Archiwum Narodowym w Krakowie. Księga inwentarzowa i dyspozycji zamku w Podhorcach, oprócz wytycznych dla służby, zawiera spis zatytułowany Rzeczy Pańskie w Podhorcach będace, w którym uwzględniono m.in.: klejnoty, złoto, srebra, porcelanę, sukna, czapki, książki, szkło oraz naczynia9. Na kartach księgi znajdują się także najstarsze zachowane katalogi ksiąg biblioteki podhoreckiej, potwierdzające istnienie księgozbioru Rzewuskich w I połowie XVIII wieku. Wspomniane inwentarze biblioteki to Cathalogus

\footnotetext{
4 A. Hanaka, Leon Rzewuski kustosz kolekcji w Podhorcach, „Muzealnictwo”, 2007, nr 48, s. 69; S. J., Jeszcze coś o Podhorcach (list do przyjaciela.), „Rozmaitości”, 1828, nr 34, s. 280; A. P. Pijanowski, Podhorce, „Nowa Szkoła”, 1997, nr 9, s. 56; J. M. Marszalska, op. cit., s. 129.

5 Zob. K. Paduch, Pałac w Podhorcach $w$ latach 1865-1939. Stan badań i postulaty badawcze, , Saeculum Christianum", 2016, t. 23, s. 223-231.

6 Zob. M. Bogucka, Życie codzienne - spory wokół profilu badań i definicji, „Kwartalnik Historii Kultury Materialnej", 1996, nr 3, s. 248-253.

7 I. Kulesza-Woroniecka, Współpracownicy Izabeli Branickiej w latach 1771-1808, „Studia Podlaskie”, 2012, t. 20, s. 155-156.

8 Księga inwentarzowa i dyspozycji zamku w Podhorcach 1749-1751, 1781, Archiwum Narodowe w Krakowie (dalej: ANKr.), Archiwum Sanguszków (dalej: Arch. Sang.), sygn. Podh II 33, s. 1-92.

W inwentarzu Narodowego Archiwum w Krakowie prawdopodobnie popełniono błąd, gdyż w księdze inwentarzowej znajdują się dokumenty sporządzone już w 1748 r. Natomiast przy niektórych dokumentach zaznaczony jest rok 1754. Zaś na końcu księgi znajduje się pojedynczy dokument $W$ pałacu Podhoreckim powstały w $1781 \mathrm{r}$. Należy przyjąć, iż dyspozycje znajdujące się na wcześniejszych kartach księgi powstały ok. połowy XVIII w. Te nieścisłości mogą wynikać z faktu, iż obecnie dokument ten zachował się w formie luźnych kart w poszycie. Na zachowanych stronach w dokumencie nie zawsze widoczne są numery stron nadane przez archiwistę lub nie są one w pełni czytelne, dlatego w przypisach zaznaczano zawsze tytuł dyspozycji. Zob. W pałacu Podhoreckim, w: Księga inwentarzowa i dyspozycji zamku w Podhorcach 1749-1751, 1781, ANKr., Arch. Sang., sygn. Podh. II 33, s. 89-92; Dyspozycya na dawanie z armat zamku podhoreckiego die 14 Feb[ruarius] 1748 a[nn]o w Podhorcach spisane, w: Księga inwentarzowa i dyspozycji zamku w Podhorcach 1749-1751, 1781, ANKr., Arch. Sang., sygn. Podh. II 33, s. 3-4.

9 Rzeczy Pańskie w Podhorcach będace, w: Księga inwentarzowa i dyspozycji zamku w Podhorcach 1749-1751, 1781, ANKr., Arch. Sang., sygn. Podh. II 33, s. 15-39.
} 
Librorum Latinorum oraz Cathalogus des Livres François ${ }^{\mathrm{I}}$. Większość znajdujących się w księdze inwentarzowej dyspozycji nie ma daty, która jednoznacznie wskazywałaby na czas ich powstania, niemniej należy przyjąć na podstawie dat umieszczonych przy innych zapiskach znajdujących się w dokumencie, iż powstały one pomiędzy rokiem I748 a I754. Księga zawierająca spis inwentarzowy oraz wytyczne dla służby pałacu podhoreckiego ma wymiar 30,5 cm $\times 19,5 \mathrm{~cm}$ i oprawiona jest w zniszczony gruby papier ${ }^{\mathrm{II}}$.

Księga zawierająca dyspozycje pozostawione przez Wacława Rzewuskiego dla służby rozpoczyna się od zalecenia dokładnego i szczegółowego przekazywania sobie przez służbę wytycznych, w celu najdokładniejszego wypełnienia obowiązków zgodnie z zaleceniami właściciela pałacu. Ponadto hetman przypomina o obowiązku częstego czytania instrukcji dotyczącej funkcjonowania pałacu oraz postępowania według zawartych w niej zaleceńn ${ }^{12}$. Wśród zachowanych instrukcji można wyróżnić dyspozycje dotyczące różnych sfer funkcjonowania staropolskiej rezydencji magnackiej, którą był bez wątpienia pałac w Podhorcach. Wacław Rzewuski wydał swojej służbie dyspozycje dotyczące: witania gości, kuchni i stołu rezydencji, bezpieczeństwa oraz ogrzewania i oświetlenia pałacu, a także stajni podhoreckiej³.

\section{Witanie gości rezydencji}

Pierwszą instrukcją zachowaną w księdze regulującej funkcjonowanie dworu podhoreckiego jest dyspozycja dotycząca witania gości wystrzałem z armat, zatytułowana Dyspozycya na dawanie z armat zamku podhoreckiego die I4 Feb[ruarius] I748 a[nn]o w Podhorcach spisane $^{14}$. W instrukcji zanotowano, iż o liczbie wystrzałów z armat na powitanie i odjazd gości przybyłych do rezydencji decydowali właściciele pałacu, czyli Wacław Rzewuski oraz jego żona Anna z Lubomirskich Rzewuska (ok. I7I7-I763). Wystrzałem z armat - tzw. ogniem ordynaryjnym, według instrukcji wystrzeliwanym z trzech dział, słudzy mieli zawsze witać biskupa, wojewodę, kasztelana, ministra, urzędników królewskich oraz litewskich, a także generałów i majorów ${ }^{15}$. Mowa tam także o ogniu „extraordynaryjnym”, wystrzeliwanym z sześciu dział, którym nie należało witać gości bez wyraźnej dyspozycji hetmana $^{16}$. Instrukcja ta zawiera ponadto szereg nakazów dla sług oddających wystrzały. Właściciel rezydencji napomina służbę, aby ta dobrze nabijała działka, ażeby te wydawały huczne i głośne wystrzały. Przypomina również, aby w pomieszczeniu, z którego wydawane są wystrzały, zawsze znajdowała się woda na wypadek ewentualnego pożaru ${ }^{17}$.

10 Cathalogus Librorum Latinorum, w: Księga inwentarzowa i dyspozycji zamku w Podhorcach 1749-1751, 1781, ANKr., Arch. Sang., sygn. Podh. II 33, s. 24-29; Cathalogus des Livres François, w: Księga inwentarzowa i dyspozycji zamku w Podhorcach 1749-1751, 1781, ANKr., Arch. Sang., sygn. Podh. II 33, s. 29-35. Por. K. Paduch, Biblioteka..., s. 39-44.

11 Księga inwentarzowa i dyspozycji..., s. 1-92.

12 Ibidem, s. 2.

13 Ibidem, s. 1-92.

14 Dyspozycya na dawanie z armat zamku podhoreckiego die 14 Feb[ruarius] 1748 a[nn]o..., s. 3-4.

15 Ibidem.

16 Ibidem, s. 4.

17 Ibidem, s. 3. 


\section{Kuchnia i stól w pałacu}

Kuchnia oraz służba kuchenna pełniła na dworze magnata ogromną rolę. Dobrze funkcjonująca kuchnia wpływała, jak zaznacza Agnieszka Słaby, na postrzeganie statusu magnata, podnosząc jego rangę i prestiz $\dot{z}^{18}$. W celu sprawnego zorganizowania kuchni Wacław Rzewuski przygotował Dyspozycyę względem stołów, tak dla Państwa jako i dla dworzan tudzież względem porcji dla ludzi stużacych ${ }^{\text {19 }}$. Za posiłki wydawane w rezydencji podhoreckiej odpowiadał Wojciech Józef Longin Węgleński (zm. I786), podstoli buski ${ }^{20}$. Do jego obowiązków należało ponadto wydawanie produktów potrzebnych do przygotowania posiłków, czyli - jak wymieniono w instrukcji - m.in. mięsa, słoniny, kur, masła, jaj, ryb ${ }^{21}$. Pełnił on więc w pałacu także funkcję szafarza, czyli osoby zarządzającej zapasami żywności dworu². W dyspozycji hetman napomina kucharzy odnośnie do dodawania przypraw do potraw, pisząc: „korzeni teraz niegdzie [w] podobnych kuchniach nie zażywają, dlatego nie mają dawać ze skarbu żadnych korzeni do potraw, wyjąwszy pieprz i imbir, jednak nie powinny być dawane [do] potrawy na stół Pański, chyba tylko do PP. Dworzan"²3. Rzewuski zwraca także uwagę kucharzy, aby potrawy na stół były przygotowywane w należyty oraz staranny sposób ${ }^{24}$.

W instrukcji kucharze otrzymali także wytyczne dotyczące właściwego przygotowania niektórych potraw: ,potaź ${ }^{25}$, kiedy jest dobry powinien być rumiany, klarowny, czysty, nie ciemny, ani gęsty, siekaniny, mięsa i chleba nie powinno być nazbyt w potaziu, ale raczej mniej niż więcej. Rosół także powinien być czysty i klarowny, mięso w nim nie brudne, ale białe i także nie nazbyt mięsa, raczej mniej niż więcej. Pieczyste powinno być rumiane, niespalone"26. W kolejnym punkcie instrukcji hetman chwali kucharzy za przygotowywanie niektórych dań, chociażby rosołu, potaziu, zrazików drobnych cudzoziemskich. Z kolei zwraca uwagę kucharzom, aby podszkolili się z przygotowywania potraw z warzywami, m.in. jarmużu z kiełbaskami, marchewki lub rzepy z tłustym mięsem wołowym lub baranim albo przepiórkami ${ }^{27}$. W końcowych punktach dyspozycji hetman przypomina służbie kuchennej, aby chleb wypiekany był ,piękny, wysoki, niepłaski, okrągły, a nie podługowaty, rumiany, nie białawy”28. Wśród wskazówek dotyczących przygotowywania potraw hetman wydał

\footnotetext{
18 A. Słaby, Rządzicha oleszycka. Dwór Elżbiety z Lubomirskich Sieniawskiej jako przykład patronatu w czasach saskich, Kraków 2014, s. 228-229.

19 Dyspozycya względem stołów, tak dla Państwa jako i dla dworzan tudzież względem porcji dla ludzi służacych, w: Księga inwentarzowa i dyspozycji zamku w Podhorcach 1749-1751, 1781, ANKr., Arch. Sang., sygn. Podh. II 33, s. 63-64.

20 Wojciech Józef Longin Węgliński (Węgleński) h. Godziemba (zm. 1786) - w latach 1740-1766 podstoli buski, zaś w latach 1766-1786 kasztelan chełmski. Zob. Urzędnicy województwa betskiego i ziemi chetmskiej XIV-XVIII wieku. Spisy, oprac. H. Gmiterek, R. Szczygieł, red. A. Gąsiorowski, Kórnik 1992, s. 274, nr 563, 1123.

21 Ibidem, s. 63.

22 W. Czapliński, J. Długosz, Życie codzienne magnaterii polskie w XVII wieku, Warszawa 1976, s. 59.

23 Dyspozycja względem stołów..., s. 63.

24 Ibidem.

25 Potaź - (fran. potage) rosół lub wywar z mięsem lub warzywami, potrawa pochodząca z kuchni francuskiej, będąca daniem wyrafinowanym i eleganckim. Zob. S. Czerniecki, Compendium ferculorum albo Zebranie potraw, opr. J. Dumanowski, M. Spychaj, Warszawa 2010, s. 199-200.

26 Dyspozycja względem stołów..., s. 63.

27 Ibidem.

28 Ibidem, s. 64.
} 
również dyspozycję dotyczącą podawania deserów, pisząc: „ciast dwa półmiski, kiedy gość jest, dawać może [kucharz], torty zaś rzadko dawać, chyba kiedy wielki gość"29.

Wacław Rzewuski zatrudniał w pałacu podhoreckim cukiernika, co nie było niczym szczególnym, gdyż często na dworach magnackich wśród służby kuchennej pracowała osoba odpowiadająca za przygotowanie deserów ${ }^{30}$. Hetman w dyspozycji zostawił szczegółowe wytyczne dotyczące pracy i obowiązków cukiernika, pisząc: „kiedy zaś gość jest bardzo znaczny może między cukry dać [cukiernik] parmezanu kilka talerzy, jako ciężko pokrajanego, a jak gość nie bardzo extraordynaryjny to nie parmezan, ale syr holenderski dawać, prócz syrów zaś i fruktów między cukry daje się migdały w skorupkach, figi, tureckie orzechy, kasztany, daktyle zaś nie kupować, bo się bardzo szybko psują”’’. W końcowych punktach dyspozycji właściciel Podhorców przypomina służbie kuchennej o punktualnym wydawaniu posiłków - obiadu w południe, z kolei kolacji o godzinie siódmej wieczorem ${ }^{32}$.

W księdze znajduje się także instrukcja zatytułowana Dyspozycya względem piwnicy, zawierająca wytyczne dotyczące funkcjonowania piwnicy33. W instrukcji ponownie hetman wymienia osobę wspomnianego wyżej Węgleńskiego, który, oprócz wcześniej wymienionych obowiązków, miał także nadzorować piwnicę podhorecką. Do jego zadań należało m.in. rozcieńczanie miodu według określonych zasad ${ }^{34}$. Prawdopodobnie w późniejszym czasie, w celu uzupełnienia i uszczegółowienia zasad opieki i korzystania z win i miodów zgromadzonych w Podhorcach, Wacław Rzewuski przygotował Przydatek do dyspozycyi piwnicy ${ }^{35}$. W punktach instrukcji określił, iż zarządca rezydencji miał pełnić nadzór nad kluczem oraz korzystaniem z piwnicy, a także osobiście nadzorować każdorazowe otwieranie piwnicy $z$ trunkami ${ }^{36}$.

\section{Bezpieczeństwo rezydencji}

W zachowanej księdze można wyróżnić dyspozycje dotyczące bezpieczeństwa pałacu podhoreckiego. Wacław Rzewuski wydał instrukcje dotyczące warty w pałacu, a także działań, jakie miała podejmować służba celem ochrony rezydencji przed złodziejami, pożarem, a także przed szkodami powstałymi w wyniku przeciekania jej dachu37.

\footnotetext{
29 Ibidem.

30 Ibidem; W. Czapliński, J. Długosz, op. cit., s. 59.

31 Dyspozycya względem stołów..., s. 64.

32 Ibidem.

33 Dyspozycya względem piwnicy, w: Księga inwentarzowa i dyspozycji zamku w Podhorcach 1749-1751, 1781, ANKr., Arch. Sang., sygn. Podh. II 33, s. 64.

34 Ibidem.

35 Przydatek do dyspozycyi piwnicy, w: Księga inwentarzowa i dyspozycji zamku w Podhorcach 1749-1751, 1781, ANKr., Arch. Sang., sygn. Podh. II 33, s. 76.

36 Ibidem.

37 Zob. Dyspozycya względem piwnicy, s.64-65; Dyspozycya względem ostrożności od złodzieja, w: Księga inwentarzowa i dyspozycji zamku w Podhorcach 1749-1751, 1781, ANKr., Arch. Sang., sygn. Podh. II 33, s. 87; Dyspozycya względem ostrożności od ognia, w: Księga inwentarzowa i dyspozycji zamku w Podhorcach 1749-1751, 1781, ANKr., Arch. Sang., sygn. Podh. II 33, s. 87-88; Dyspozycya względem ostrożności od zaciekania deszczem i zawiania śniegiem przez dachy, w: Księga inwentarzowa i dyspozycji zamku w Podhorcach 1749-1751, 1781, ANKr., Arch. Sang., sygn. Podh. II 33, s. 66.
} 
W kolejnych punktach Dyspozycyi względem piwnicy $3^{38}$ hetman wydaje służbie polecenia dotyczące zachowania bezpieczeństwa w rezydencji podhoreckiej. Hetman zwraca uwagę służbie na bezpieczeństwo pomieszczenia nazywanego Skarbczykiem Górnym, przypominając służbie o zamykaniu drzwi oraz niewpuszczaniu do tego pomieszczenia osób postronnych $^{39}$. Badacze wnętrz rezydencji podhoreckiej, Jan K. Ostrowski oraz Jerzy T. Petrus, ustalili podczas swoich badań, iż na drugim piętrze pałacu znajdował się pokój zwany Skarbczykiem $^{40}$. W pomieszczeniu tym przechowywano księgi oraz pieniądze należące do hetmana Rzewuskiego ${ }^{4}$. Ponadto służący Wolski lub osoba wybrana przez zarządcę pałacu zostali wyznaczeni do opieki nad srebrami znajdującymi się w pałacu. Do obowiązków tegoż Wolskiego należało codzienne sprawdzanie, czy w całym pałacu nie zginęły żadne srebra. W razie zauważenia kradzieży miał on niezwłocznie poinformować zarządcę pałacu ${ }^{42}$.

Z kolei bezpieczeństwa rodziny Rzewuskich oraz gości rezydencji pilnowała warta znajdująca się w bramie przed pałacem podhoreckim. W instrukcji hetman stanowczo nakazał sługom pełniącym wartę, aby nie wpuszczali do pałacu nikogo podejrzanego. Podobne zalecenia otrzymali słudzy pełniący wartę $\mathrm{w}$ sieni rezydencji ${ }^{43}$.

W dyspozycji umieszczone zostały także punkty dotyczące bezpieczeństwa pokoi na pierwszym piętrze pałacu. Rzewuski pozostawił służbie szczegółowe wytyczne dotyczące zamykania pokoi pierwszego piętra pałacu, nakazując: „Brat Benedykt nie powinien otwierać [drzwi] do Chińskiego Pokoju, tylko na mszę i na litanię, a prócz tego powinny być zawsze drzwi zamknięte z Chińskiego Pokoju do sieni Kaplicznej, chybaby jaka przypadła potrzeba te drzwi otworzyć z rozkazu Państwa lub dyspozycję mającego. W nocy jednak nie mają być nigdy otwarte, a jeśliby gość stał na górze, to powinien przestrzegać brat Benedykt, żeby zaraz drzwi zamykać, jak gość na noc do stancji swojej odejdzie"44.

Z kolei w następnym punkcie Rzewuski zostawił szczególne wytyczne dotyczące bezpieczeństwa Pokoju Zielonego, pełniącego funkcję sypialni hetmana oraz jego prywatnej kancelarii oraz archiwum ${ }^{45}$. Wacław Rzewuski zaznaczył w instrukcji, iż pod jego nieobecność goście nie powinni być umieszczani w Pokoju Zielonym. Biorąc jednak pod uwagę różne ewentualności, hetman zaznacza, iż gdyby służba musiała jednak umieścić gościa w jego prywatnym apartamencie, to powinna zapieczętować szafy i kominy, zaś przedmioty prywatne przenieść do archiwum ${ }^{46}$. W celu zabezpieczenia dokumentów prywatnych hetman nakazał służbie, aby zawsze pod jego nieobecność kufer z dokumentami był umieszczany w archiwum. Rzewuski wydał także dyspozycję, aby w Pokoju Zielonym

\footnotetext{
38 Zachowana w księdze dyspozycji kolejność kart wskazuje, iż w wytycznych dotyczących piwnicy zostały zawarte instrukcje dotyczące bezpieczeństwa pałacu. Na podstawie analizy dokumentu można stwierdzić, iż prawdopodobnie kolejność kart w księdze nie zachowała się w pierwotnym stanie, a instrukcja dotycząca bezpieczeństwa pałacu zachowała się we fragmencie. Zob. Dyspozycya względem piwnicy, s. 64-65, 69 .

39 Ibidem, s. 65.

40 J. K. Ostrowski, J. T. Petrus, op. cit., s. 29.

41 K. Paduch, Biblioteka..., s. 119.

42 Dyspozycya względem piwnicy, s. 65.

43 Ibidem.

44 Ibidem.

45 Ibidem; J. K. Ostrowski, J. T. Petrus, op. cit., s. 27.

46 Dyspozycya względem piwnicy, s. 65.
} 
pod jego nieobecność, w lecie czy zimie, spał zawsze lokaj lub paź ${ }^{47}$. Skrupulatne dbanie o przedmioty oraz dokumenty znajdujące się w Pokoju Zielonym nie powinno dziwić, gdyż w pomieszczeniu tym hetman przechowywał stworzoną przez siebie bibliotekę ${ }^{48}$.

Wydanie przez hetmana tak szczegółowych wytycznych dotyczących bezpieczeństwa pierwszego piętra wydaje się uzasadnione - to właśnie na pierwszym piętrze znajdowały się chociażby apartamenty hetmana Rzewuskiego oraz jego żony Anny z Lubomirskich Rzewuskiej. W połowie XVIII wieku kondygnacja ta składała się z jedenastu pomieszczeń i stanowiła reprezentacyjną część rezydencji podhoreckiej49.

Hetman, w celu ochrony znajdujących się w rezydencji cennych przedmiotów, zostawił służbie Dyspozycyę względem ostrożności od złodzieja ${ }^{50}$. Zawarte w instrukcji dwa pierwsze punkty dotyczą ochrony dokumentów i ksiąg znajdujących się w archiwum. W dyspozycji szczegółowo zaznaczono, iż żelazne drzwi oraz okiennice archiwum powinny być zawsze zamknięte, zaś do archiwum nie mógł nikt wchodzić bez, jak zapisano w instrukcji - "Pana Dworzanina", który ma w rezydencji służbę ${ }^{5 I}$. Kolejnym miejscem w pałacu, które podlegało szczegółowej ochronie, był wspominany Skarbczyk Górny. W celu zapewnienia należytej ochrony przedmiotom przechowywanym w Skarbczyku Górnym, w pomieszczeniu tym miał sypiać „mozaista”. Ponadto hetman szczegółowo zaznaczył, iż do obowiązków „mozaisty" należało sprawdzanie trzy razy dziennie (rano, około południa oraz wieczorem), czy wszystkie cenne przedmioty znajdują się nadal w miejscu swojego przechowywania ${ }^{52}$. Jan K. Ostrowski i Jerzy T. Petrus ustalili, iż funkcję „mozaisty” pełnił Antoni Nowicki z Oleska ${ }^{53}$.

W księdze znajduje się również niezwykle szczegółowa Dyspozycya względem ostrożności od ognia, zawierająca w dziewięciu punktach wytyczne dotyczące ochrony pałacu w Podhorcach przed wybuchem pożaru ${ }^{54}$. W pierwszym punkcie hetman nakazał dbać o drożność przewodów kominowych. W dyspozycji zaznaczono, iż każdego pierwszego i piętnastego dnia miesiąca, zaczynając od miesięcy zimowych, czyli od października do kwietnia, kominiarz powinien pilnie i dokładnie czyścić wszystkie kominy w rezydencji55. Z kolei w następnych punktach dyspozycji wyznaczono miejsca rozmieszczenia w rezydencji przedmiotów oraz zbiorników wodnych mających szybko i skutecznie ugasić ewentualny pożar. Hetman Wacław Rzewuski szczegółowo nakazał, aby wanienka jedna o pojemności ośmiu garncó $w^{56}$ i konewka jedna o pojemności półtora garnca były zawsze napełnione wodą i ustawione w następujących miejscach: kuchni na parterze, na Galerii Karmazynowej przy Sali Stołowej na pierwszym piętrze, a także dwie wanienki i dwie konewki miały się znajdować na drugim piętrze $\mathrm{w}$ dwóch pomieszczeniach określonych w wytycznych gale-

47 Ibidem.

48 Zob. K. Paduch, Biblioteka..., s. 111-118.

49 Zob. J. K. Ostrowski, J. T. Petrus, op. cit., s. 14-28.

${ }^{50}$ Dyspozycya względem ostrożności od złodzieja, s. 87.

51 Ibidem.

52 Ibidem; K. Paduch, Biblioteka ..., s. 119.

53 J. K. Ostrowski, J. T. Petrus, op. cit., s. 29.

${ }_{54}$ Dyspozycya względem ostrożności od ognia, s. 88; K. Paduch, Biblioteka..., s. 123-124.

55 Dyspozycya względem ostrożności od ognia, s. 88.

${ }_{56}$ Garniec jednostka miary płynów. Garniec krakowski liczył 3,2-3,3 1, natomiast garniec warszawski liczył 3,76-3,90 1. Zob. J. Szymański, Nauki pomocnicze historii, Warszawa 2012, s. 169-170. 
rią drewnianą 57 . Pisał też o sprzętach ułatwiających gaszenie pożaru: przynajmniej jedna drabina powinna znajdować się zawsze w Galerii Karmazynowej przy Sali Stołowej, zaś przynajmniej trzy haki oraz trzy siekierki miały być zawsze umieszczone w kordegardzie ${ }^{5}$. Rozmieszczenia wody i sprzętów ułatwiających gaszenie pożaru dopilnować miała osoba odpowiadająca za przestrzeganie dyspozycji w pałacu ${ }^{59}$. W Dyspozycyi względem ostrożności od ognia Wacław Rzewuski zabronił palenia świec oraz ognia na drugim piętrze pałacu. Biorąc pod uwagę każdą ewentualną sytuację, zaznaczył, iż nie należy umieszczać gości w pokojach drugiego piętra, ale gdyby zaszła jednak taka konieczność, nakazał wyznaczyć najpilniejszego służącego, aby ten czuwał pod pokojem gościa i pilnował, aby żaden pożar nie wybuchł w rezydencji ${ }^{60}$. Dodatkowo hetman nakazał zarządcy pałacu wyznaczyć osobę ze służby, która przez okres tygodnia pilnowałaby gaszenia świec w rezydencji. Do obowiązków wyznaczonego służącego należało, zarówno w okresie zimowym jak i letnim, sprawdzanie przed pójściem spać, czy wszystkie świece w rezydencji zostały pogaszone. Wyznaczony służący, w celu lepszego dochowania ostrożności wobec zagrożenia ogniem, miał sypiać w Sali Stołowej ${ }^{6}$. Rzewuski zwraca służbie także uwagę, iż ze szczególną troską należy pilnować Pokoju Żółtego, będącego sypialnią jego żony, pod jej nieobecność. Pomieszczenie to, jak zaznacza, powinno być ogrzewane ze względu na znajdujące się w nim kanarki i ptaszki należące do jego małżonki ${ }^{62}$. Ponadto hetman, ponownie biorąc pod uwagę każdą ewentualność, przypomina, aby mieszkańcom Podhorców, mającym domy w okolicach pałacu, także przypominać o ostrożności przeciwpożarowej ${ }^{63}$.

Problem zabezpieczenia rezydencji podhoreckiej przed pożarem widoczny jest także $\mathrm{w}$ innych dokumentach zachowanych $\mathrm{w}$ archiwum podhoreckim ${ }^{64}$. W księdze zatytułowanej Miscellanea znajduje się dyspozycja wydana przez hetmana przed wyjazdem do Warszawy 9 września 1754 roku. Rzewuski przypomina w niej o systematycznym czytaniu i pilnowaniu zaleceń dotyczących zagrożenia ogniem. Szczególnie zwraca uwagę służby na bezpieczeństwo Pokoju Zielonego. W celu ochrony dokumentów archiwalnych oraz biblioteki zgromadzonej w Pokoju Zielonym hetman nakazał, aby spał w nim Magierowicz ${ }^{65}$. Kazimiera Maksimowicz, na podstawie analizy korespondencji hetmana z synem Sewerynem z lat I766-I779, wysuwa przypuszczenia, iż Rzewuski ogromnie bał się pożaru, a nawet miał fobię na punkcie pożaru w rezydencji w Podhorcach ${ }^{66}$.

\footnotetext{
57 Dyspozycya względem ostrożności od ognia, s. 88.

58 Ibidem.

59 Ibidem.

60 Ibidem.

61 Ibidem.

62 Ibidem, s. 87; J. K. Ostrowski, J. T. Petrus, op. cit., s. 24.

${ }^{63}$ Dyspozycya względem ostrożności od ognia, s. 87.

${ }^{64}$ Zob. Dyspozycya ImciPa Kozłowskiemu die 19 maij 1754, w: Miscellanea [XVIII wiek], ANKr., Arch. Sang., sygn. Podh. II 230, s. 174-175; Dyspozycya Imci Panu Kicerowi die 21 maij 1754 a[nn]o, w: Miscellanea [XVIII wiek], ANKr., Arch. Sang., sygn. Podh. II 230, s. 180-181; K. Paduch, Biblioteka ..., s. 123-124.

${ }_{65}$ Dyspozycya JmP. Sidorozkiemu dana wiezdzaiac z Podhorzec na Chetm do Warszawy die 97 ibris 1754 A[nno., w: Miscellanea [XVIII wiek], ANKr., Arch. Sang., sygn. Podh. II 230, s. 333-334.

66 Zob. K. Maksimowicz, Hetman Seweryn Rzewuski pod sterami swego ojca Wacława w latach 1774-1779, ,Ze skarbca kultury", 1989, z. 49, s. 164; K. Paduch, Biblioteka..., s. 123-124; List Wacława Rzewuskiego do syna Seweryna Rzewuskiego z dnia 14 grudnia 1775, w: Listy Wacława Rzewuskiego do syna Wacława, ANKr., Arch. Sang., sygn. Podh. II 152, b.s.; List Wacława Rzewuskiego do syna Seweryna Rzewuskiego z dnia 15 czerwca
} 
W Księdze inwentarzowej $i$ dyspozycji zamku w Podhorcach hetman Wacław Rzewuski pozostawił także Dyspozycyę względem ostrożności od zaciekania deszczem i zawiania śniegiem przez dachy ${ }^{67}$. W wydanych wytycznych Rzewuski wskazuje służącego Sokołowskiego jako osobę odpowiedzialną za zabezpieczenie pałacu przed dużymi opadami deszczu lub śniegu. Wydając instrukcje dla służby, hetman postępuje zawsze przezornie, biorąc pod uwagę różne ewentualne sytuacje. W punktach tej dyspozycji także zaznacza zapobiegawczo, iż gdyby służący Sokołowski, na przykład z powodu choroby, nie mógł wywiązać się ze swoich obowiązków, miała zastąpić go osoba wyznaczona przez zarządcę pałacu ${ }^{68}$. W wytycznych zostały szczegółowo określone zadania Sokołowskiego - mianowicie miał on każdego pierwszego dnia miesiąca sprawdzać dachy. Z kolei w sytuacji przeciekania dachu odpowiadał za podstawienie naczyń w celu niedopuszczenia do zalania stropów i sufitów. Szczególnie solidnie i pilnie, jak zaznacza w wydanej dyspozycji hetman, służący miał wykonywać swoje obowiązki podczas ulewnych oraz częstych opadów deszczu. Ponadto odpowiadał on za odśnieżanie dachu rezydencji podhoreckiej. Do zadań służącego należało również informowanie i czuwanie nad stanem bali dachowych oraz dachówek, a także zlecenie w razie potrzeby wszelkich napraw dachu ${ }^{69}$.

\section{Oświetlenie i ogrzewanie rezydencji}

W księdze dyspozycji dla służby Wacław Rzewuski pozostawił także wytyczne dotyczące oświetlenia oraz ogrzewania pomieszczeń rezydencji podhoreckiej ${ }^{70}$. Wytyczne dla służby dotyczące używania m.in. świec oraz lamp łojowych w rezydencji podhoreckiej znajdują się w Dyspozycyi świec do zamku podhoreckiego ${ }^{71}$. W instrukcji hetman pouczył służbę, aby świece używać do wysokości dwóch palców, po czym należy je usunąć i wstawić nowe. Ponadto zaznaczył skrupulatnie liczbę świec, które służba miała umieszczać w poszczególnych pokojach pierwszego piętra pałacu. We wspominanych wcześniej pomieszczeniach, mianowicie w Pokoju Żółtym będącym sypialnią Anny z Lubomirskich Rzewuskiej oraz W zajmowanym przez siebie Pokoju Zielonym, kazał umieszczać dwie świece ${ }^{72}$. W podobnie szczegółowy sposób wydał dyspozycje względem rozmieszczenia i używania lamp i świec łojowych w pałacu. Wacław Rzewuski okréslił skrupulatnie zużycie lamp i świec łojowych, tak aby służba nie nadużywała materiałów oświetleniowych ${ }^{73}$. Nakazał służbie, aby dziennie wydawała 5 lamp łojowych, z których każda wykonana była z półtora funta łoju, oraz 29

1775, w: Listy Wacława Rzewuskiego do syna Wacława, ANKr., Arch. Sang., sygn. Podh. II 152, b.s.; List Wacława Rzewuskiego do syna Seweryna Rzewuskiego z dnia 9 grudnia 1777, w: Listy Wacława Rzewuskiego do syna Wacława, ANKr., Arch. Sang., sygn. Podh. II 152, b.s.; K. Paduch, Biblioteka ..., s. 123-124.

${ }^{67}$ Dyspozycya względem ostrożności od zaciekania deszczem..., s. 66.

68 Ibidem.

69 Ibidem.

70 Dyspozycya świec do zamku podhoreckiego, w: Księga inwentarzowa i dyspozycji zamku w Podhorcach 17491751, 1781, ANKr., Arch. Sang., sygn. Podh. II 33, s. 68; Dyspozycya względem drew, w: Księga inwentarzowa i dyspozycji zamku w Podhorcach 1749-1751, 1781, ANKr., Arch. Sang., sygn. Podh. II 33, s. 76; Dyspozycya względem drew miesięcznych z dnia 20 Juli 1754, w: Księga inwentarzowa i dyspozycji zamku w Podhorcach 1749-1751, 1781, ANKr., Arch. Sang., sygn. Podh. II 33, s. 7.

71 Dyspozycya świec do zamku podhoreckiego, s. 68; K. Paduch, Biblioteka..., s. 123.

72 Dyspozycya świec do zamku podhoreckiego, s. 68.

73 Ibidem. 
świec łojowych wykonanych z dwóch funtów łoju, zaznaczając oczywiście, iż w okresie letnim zużycie materiałów oświetleniowych powinno być mniejsze niż w okresie zimowym7 ${ }^{74}$

Kolejne instrukcje wydane przez Wacława Rzewuskiego dotyczą aspektu gospodarczego funkcjonowania rezydencji. Hetman wydał szczegółowe zalecenia dotyczące przygotowywania i wykorzystywania drzewa opałowego zatytułowane Dyspozycya względem drew ${ }^{75}$. Nakazał w nich swojej służbie, aby w okresie od pierwszego kwietnia do pierwszego listopada przygotowywano drewno na potrzeby rezydencji, przywożąc do pałacu 32 fury drewna miesięcznie ${ }^{76}$. Następnie Rzewuski szczegółowo określił zużycie przygotowanego materiału opałowego. Według wytycznych służba miała palić w kominkach w godzinach porannych od dziewiątej do trzynastej, czyli przez okres czterech godzin. Z kolei wieczorem tylko trzy godziny - od szóstej do dziewiątej77. W księdze zachowała się także Dyspozycya względem drew miesięcznych z dnia 20 Juli I754. W instrukcji tej hetman przypomina służbie o wcześniej wydanej dyspozycji, ponadto nakazuje służbie podhoreckiej w każdym miesiącu letnim zwozić po 80 ton drewna. Zaznacza także, iż pod żadnym pretekstem nie wolno służbie używać w lecie drzewa przygotowanego na zimę. Dla osób łamiących ten zakaz przewiduje Rzewuski surowe kary, włącznie ze zwolnieniem ze służby ${ }^{78}$.

\section{Wynagrodzenie dla służby}

W księdze dyspozycji dla służby hetman pozostawił także wytyczne dotyczące wydatków tygodniowych. W zachowanej Dyspozycyi względem expensy pieniężnej tygodniowej poucza służbę, jak powinna postępować z pieniędzmi na wydatki ${ }^{79}$. W instrukcji hetman zaznacza, iż arendarz podhorecki w każdą niedzielę powinien wydawać służącemu odpowiadającemu za pałac ,złotych dziewięćdziesiąt to jest pięćdziesiąt cztery monetą, a trzydzieści sześć złotem". Z podanej sumy Wacław Rzewuski nakazuje część pieniędzy przeznaczyć na drobne nadzwyczajne wydatki, natomiast resztę sumy oszczędzać na następne tygodnie. Poleca także część pieniędzy przekazywać księdzu Bazylianowi na odprawienie mszy świętej w piątek ${ }^{80}$.

\section{Stajnia podhorecka}

Wśród pozostawionych w księdze dyspozycji dla służby znajdują się również wytyczne dotyczące funkcjonowania stajni podhoreckiej. W instrukcji zatytułowanej Dyspozycya względem expensy owsa i siana Rzewuski szczegółowo określił obowiązki Kozłowskiego, pełniącego prawdopodobnie funkcję koniuszego w tej stajni ${ }^{81}$. Do obowiązków stajennego należało spisywanie wydanego owsa i siana w zestawieniu sporządzanym co miesiąc w specjalnej

\footnotetext{
74 Ibidem.

75 Dyspozycja względem drew, s. 76

76 Ibidem.

77 Ibidem.

78 Dyspozycya względem drew miesięcznych..., s. 7.

79 Dyspozycya względem expensy pieniężnej tygodniowej, w: Księga inwentarzowa i dyspozycji zamku w Podhorcach 1749-1751, 1781, ANKr., Arch. Sang., sygn. Podh. II 33, s. 69.

80 Ibidem.

${ }^{81}$ Dyspozycya względem expensy owsa i siana, w: Księga inwentarzowa i dyspozycji zamku w Podhorcach 17491751, 1781, ANKr., Arch. Sang., sygn. Podh. II 33, s. 75.
} 
księdze. Zestawienie to miał obowiązek co miesiąc przedstawiać hetmanowi do akceptacji ${ }^{82}$. Ponadto stajenny otrzymał zasadnicze wytyczne dotyczące karmienia koni gości rezydencji podhoreckiej. W instrukcji zapisano: „Gościowi żadnemu bez rozkazu Pana lub Pani owsa ani siana nie dawać”. Zaznaczyć należy, iż w instrukcji wymieniono także gości, których konie należy karmić, jak zaznaczono, „,proporcjonalnie"\$3. Odnotować należy, iż oddzielny punkt w instrukcji dotyczył koni, jak zapisano ,pięknych i rosłych”, którym hetman nakazał dawać „siano piękne i dobry owies" ${ }^{\text {". }}$. Zapis ten świadczy o zamiłowaniu hetmana do dorodnych koni. Pasja do koni była pielęgnowana w rodzinie, gdyż odziedziczył ją wnuk, kolejny właściciel rezydencji podhoreckiej, Wacław Seweryn „Emir” Rzewuski (I784-I83I), który w swojej stadninie w Sawraniu hodował czystej krwi konie arabskie ${ }^{85}$.

\section{Zakończenie}

Wacław Rzewuski wydawał instrukcje dotyczące różnych sfer funkcjonowania rezydencji podhoreckiej. W zachowanych dyspozycjach daje się zauważyć szczegółowość oraz przezorność właściciela rezydencji. Hetman pozostawił w Księdze inwentarzowej $i$ dyspozycji zamku w Podhorcach wytyczne dla służby, biorąc pod uwagę różne ewentualne scenariusze, regulując tym samym wszystkie aspekty pracy służących, których dotyczyły zachowane dyspozycje ${ }^{86}$. Niniejszy artykuł uzupełnia dotychczasowy stan badań nad rezydencją podhorecką i być może przyczyni się do dalszych prac nad funkcjonowaniem służby oraz dworu podhoreckiego rodziny Rzewuskich.

\section{Guidelines of the hetman Waclaw Rzewuski (1706-1779) for the palace service. A contribution to the functioning of the Podhorce residence in the middle of the $18^{\text {th }}$ century Summary}

From 1729 the Palace in Podhorce was the residence of Grand Crown Hetman Waclaw Rzewuski (I706-I779). Hetman arranged a magnificent Old Polish magnate residence in the Podhorecki palace, having souvenirs of representatives of the Sobieski family and the Koniecpolski family, as well as a gallery of works of art, an armory and a library. This article is an attempt to present the functioning of the Podhorce residence in the light of the guidance kept in the Book of inventory and instructions of the Podhorce castle from I745-I754. Among the preserved guidelines, one can distinguish instructions concerning various areas of the functioning of the Podhorce residence, namely: welcoming guests, the kitchen and the table of residence, security, heating and lighting of the palace, as well as the Podhorce stables.

\footnotetext{
82 Ibidem.

83 Ibidem.

84 Ibidem.

85 Ibidem, s. 75. W. Pruski, Dwa wieki hodowli koni arabskich (1778-1978) i jej sukcesy na świecie, Warszawa 1983, s. 15-16, 22-37; S. Kieniewicz, Rzewuski Wacław Seweryn (1784-1831), w: Polski Stownik Bibliograficzny, t. 34, red. H. Markiewicz, Wrocław-Warszawa-Kraków 1992-1993, s. 180-183.

86 Księga inwentarzowa i dyspozycji..., s. 1-92.
} 
Keywords: Waclaw Rzewuski (I706-I779), Podhorce, palace in Podhorce, functioning of the residence

\section{BIBLIOGRAFIA}

I. Źródła Archiwalne

Archiwum Narodowe w Krakowie (ANKr.)

Cathalogus des Livres François, w: Księga inwentarzowa i dyspozycji zamku w Podhorcach I749-I75I, I78I, ANKr., Archiwum Sanguszków (dalej: Arch. Sang.), sygn. Podh. II 33 , s. 29-35.

Cathalogus Librorum Latinorum, w: Księga inwentarzowa i dyspozycji zamku w Podhorcach I749-I75I, I78I, ANKr., Arch. Sang., sygn. Podh. II 33, s. 24-29.

Dyspozycya ImciPa Kozłowskiemu die I9 maij I754, w: Miscellanea [XVIII wiek], ANKr., Arch. Sang., sygn. Podh. II 230, s. I74-I75.

Dyspozycya Imci Panu Kicerowi die 2I maij I754 a[nn]o, w: Miscellanea [XVIII wiek], ANKr., Arch. Sang., sygn. Podh. II 230, s. I80-I8I.

Dyspozycya JmP. Sidorozkiemu dana wiezdzaiac z Podhorzec na Chetm do Warszawy die 9 7ibris I754 A[nn]o., w: Miscellanea [XVIII wiek], ANKr., Arch. Sang., sygn. Podh. II 230, s. 333-334.

Dyspozycya na dawanie z armat zamku podhoreckiego die I4 Feb[ruarius] I748 a[nn]o w Podhorcach spisane, w: Księga inwentarzowa i dyspozycji zamku w Podhorcach I749-I75I, I78I, ANKr., Arch. Sang., sygn. Podh. II 33, s. 3-4.

Dyspozycya świec do zamku podhoreckiego, w: Księga inwentarzowa i dyspozycji zamku w Podhorcach I749-I75I, I78I, ANKr., Arch. Sang., sygn. Podh. II 33, s. 68.

Dyspozycya względem drew miesięcznych z dnia 20 Juli I754, w: Księga inwentarzowa i dyspozycji zamku w Podhorcach I749-I75I, I78I, ANKr., Arch. Sang., sygn. Podh. II 33, s. 7.

Dyspozycya względem drew, w: Księga inwentarzowa i dyspozycji zamku w Podhorcach I749-I75I, I78I, ANKr., Arch. Sang., sygn. Podh. II 33, s. 76.

Dyspozycya względem expensy owsa i siana, w: Księga inwentarzowa i dyspozycji zamku w Podhorcach I749-I75I, I78I, ANKr., Arch. Sang., sygn. Podh. II 33, s. 75.

Dyspozycya względem ostrożności od ognia, w: Księga inwentarzowa i dyspozycji zamku w Podhorcach I749-I75I, I78I, ANKr., Arch. Sang., sygn. Podh. II 33, s. 87-88.

Dyspozycya względem ostrożności od zaciekania deszczem i zawiania śniegiem przez dachy, w: Księga inwentarzowa i dyspozycji zamku w Podhorcach I749-I75I, I78I, ANKr., Arch. Sang., sygn. Podh. II 33, s. 66.

Dyspozycya względem ostrożności od złodzieja, w: Księga inwentarzowa i dyspozycji zamku w Podhorcach I749-I75I, I78I, ANKr., Arch. Sang., sygn. Podh. II 33, s. 87.

Dyspozycya względem piwnicy, w: Księga inwentarzowa i dyspozycji zamku w Podhorcach I749-I75I, I78I, ANKr., Arch. Sang., sygn. Podh. II 33, s. 64.

Dyspozycya względem stołów, tak dla Państwa jako i dla dworzan tudzież względem porcji dla ludzi stużacych, w: Księga inwentarzowa i dyspozycji zamku w Podhorcach I749-I75I, I78I, ANKr., Arch. Sang., sygn. Podh. II 33, s. 63-64.

Dyspozycya względem expensy pieniężnej tygodniowej, w: Księga inwentarzowa i dyspozycji zamku w Podhorcach I749-I75I, I78I, ANKr., Arch. Sang., sygn. Podh. II 33, s. 69. 
Księga inwentarzowa i dyspozycji zamku w Podhorcach I749-I75I, I78I, ANKr., Arch. Sang., sygn. Podh II 33. s. I-92.

List Wacława Rzewuskiego do syna Seweryna Rzewuskiego z dnia I5 czerwca I775, w: Listy Wacława Rzewuskiego do syna Wacława, ANKr., Arch. Sang., sygn. Podh. II I52, b.s.

List Wacława Rzewuskiego do syna Seweryna Rzewuskiego z dnia 9 grudnia I777, w: Listy Wacława Rzewuskiego do syna Wacława, ANKr., Arch. Sang., sygn. Podh. II I52, b.s.

List Wacława Rzewuskiego do syna Seweryna Rzewuskiego z dnia I4 grudnia I775, w: Listy Wacława Rzewuskiego do syna Wacława, ANKr., Arch. Sang., sygn. Podh. II I52, b.s.

Przydatek do dyspozycyi piwnicy, w: Księga inwentarzowa i dyspozycji zamku w Podhorcach I749-I75I, I78I, ANKr., Arch. Sang., sygn. Podh. II 33, s. 76.

Rzeczy Pańskie w Podhorcach będace, w: Księga inwentarzowa i dyspozycji zamku w Podhorcach I749-I75I, I78I, ANKr., Arch. Sang., sygn. Podh. II 33, s. I5-39.

W pałacu Podhoreckim, w: Księga inwentarzowa i dyspozycji zamku w Podhorcach I749I75I, I78I, ANKr., Arch. Sang., sygn. Podh. II 33, s. 89-92.

Źródła drukowane

S. J., Jeszcze coś o Podhorcach (list do przyjaciela.), „Rozmaitości”, I828, nr 34, s. 279-280.

Urzędnicy województwa betskiego i ziemi chetmskiej XIV-XVIII wieku. Spisy, oprac. H. Gmiterek, R. Szczygieł, red. A. Gąsiorowski, Kórnik I992.

Opracowania

Aftanazy R., Dzieje rezydencji na dawnych kresach Rzeczypospolitej, t. 7, Wrocław-Warszawa-Kraków I995, s. 427-490.

Bania Z., Pałac w Podhorcach, „Rocznik Historii Sztuki”, I98I, t. I3, s. 97-I70.

Bańburski K., Szpunar A., Zamek w Podhorcach w posiadaniu Rzewuskich i Sanguszków, „Zamoysko-Wołyńskie Zeszyty Muzealne”, 2004, t. 2, s. I39-I53.

Bogucka M, Życie codzienne - spory wokót profilu badań i definicji, „Kwartalnik Historii Kultury Materialnej”, I996, nr 3, s.248-253.

Czapliński W., Długosz J., Życie codzienne magnaterii polskie w XVII wieku, Warszawa 1976.

Czerniecki S., Compendium ferculorum albo Zebranie potraw, opr. J. Dumanowski, M. Spychaj, Warszawa 20 Io.

Czołowski A., Dawne zamki i twierdze na Rusi Halickiej, „Teka Konserwatorska: rocznik Koła C.C. Konserwatorów Starożytnych Pomników Galicji Wschodniej”, I892, t. I, s. 96-I00.

Hanaka A., Leon Rzewuski kustosz kolekcji w Podhorcach, „Muzealnictwo”, 2007, nr 48, s. $68-77$.

Kieniewicz K., Rzewuski Wacław Seweryn (I784-I83I), w: Polski Słownik Bibliograficzny, t. 34, red. H. Markiewicz, Wrocław-Warszawa-Kraków I992-I993, s. I80-I83.

Kryczyński W., Zamek w Podhorcach, Złoczów I894.

Krzyżewski T., Rzewuski Wacław (I706-I779), w: Słownik Pracowników Książki Polskiej, red. I. Treichel, Warszawa- Łódź 1972, s. 78I-782.

Kulesza-Woroniecka I., Współpracownicy Izabeli Branickiej w latach I77I-I808, „Studia Podlaskie", 20I2, t. 20, s. I55-I74.

Maksimowicz K., Hetman Seweryn Rzewuski pod sterami swego ojca Wacława w latach I774-I779, „Ze skarbca kultury”, I989, Z. 49, s. I49-I89. 
Marszalska J. M., Biblioteka i archiwum Sanguszków: zarys dziejów, Tarnów 2000.

Ostrowski J. K., Petrus J. T., Podhorce: dzieje wnętrz pałacowych i galerii obrazów, Kraków $200 I$.

Paduch K., Biblioteka rodowa Rzewuskich h. Krzywda w Podhorcach w XVIII i XIX wieku, mps rozprawy doktorskiej.

Paduch K., Pałac w Podhorcach w latach I865-I939. Stan badań i postulaty badawcze, „Seaculum Christianum”, 20I6, t. 23, s. 223-23I.

Pijanowski A. P., Podhorce, „Nowa Szkoła”, I997, nr 9, s. 55-56.

Pruski W., Dwa wieki hodowli koni arabskich (I778-I978) i jej sukcesy na świecie, Warszawa 1983.

Słaby A., Rządzicha oleszycka. Dwór Elżbiety z Lubomirskich Sieniawskiej jako przykład patronatu w czasach saskich, Kraków $20 \mathrm{I} 4$.

Szymański J., Nauki pomocnicze historii, Warszawa 2012.

Zielińska Z., Rzewuski Wacław (I706-I779), w: Polski Słownik Biograficzny, t. 34, red. H. Markiewicz, Wrocław-Warszawa-Kraków I992-I993, s. I69-I80. 